\title{
HUTAN KOTA SUNGAILIAT SEBAGAI MEDIA DALAM MENINGKATKAN KETERAMPILAN MENULIS PADA SISWA SMPN 2 SUNGAILIAT
}

\author{
Tien Rostini \\ SMPN 2 Sungailiat \\ rostini.tien10@gmail.com
}

\begin{abstract}
Abstrak
Penelitian ini bertujuan untuk mengetahui efektivitas pemanfaatan media Hutan Kota Sungailiat dalam meningkatkan keterampilan siswa kelas VIII D di SMPN 2 Sungailiat dalam menulis teks eksposisi. Efektivitas pembelajaran dengan media Hutan Kota Sungailiat dilihat dari peningkatan keterampilan siswa dalam menulis teks eksposisi. Penelitian ini berbentuk Penelitian Tindakan Kelas (PTK) yang dilakukan dalam dua siklus. Setiap siklus dilaksanakan dengan empat langkah, yakni perencanaan, pelaksanaan, pengamatan, dan refleksi. Tindakan perbaikan pembelajarannya dilakukan dua pertemuan persiklus. Pertemuan pertama dilakukan di Hutan Kota Sungailiat untuk menentukan ide, mengumpulkan data, dan menyusun kerangka serta konsep tulisan. Pertemuan kedua dilakukan di ruang kelas untuk menyunting tulisan. Hasil penilaian setiap siklus menunjukkan adanya peningkatan hasil belajar siswa dalam bentuk keterampilan menulis eksposisi. Peningkatannya dapat dilihat dari hasil penilaian pembelajaran awal, siklus I, dan siklus II. Persentase ketuntasan kelas pada pembelajaran awal sebesar $61,76 \%$, pada siklus I, dan pada siklus II mencapai $94,12 \%$. Dengan demikian, dapat disimpulkan, bahwa pembelajaran dengan media Hutan Kota Sungailiat efektif untuk meningkatkan keterampilan menulis teks eksposisi pada siswa kelas VIII D di SMP Negeri 2 Sungailiat.
\end{abstract}

Kata Kunci: Hutan Kota Sungailiat; Media; Keterampilan Menulis; Teks Eksposisi.

\begin{abstract}
The purpose of this research is to determine the effectiveness of the use of City Forest of Sungailiata media to improving the student's skills for students in class VIII D at SMPN 2 Sungailiat in writing exposition texts. The effectiveness of learning with the City Forest of Sungailiat media can be seen from the improvement of students' skills in writing exposition text.This research is in the form of Classroom Action Research (CAR) which is conducted in two cycles.Each cycle is carried out with four steps, there are planning, implementing, observing, and reflecting. The action to improve learning is done two meetings per cycle. The first meeting was held in the City Forest of Sugailiat to determine ideas, collect data, and compile the framework and concept of writing. The second meeting was held in the classroom, to edit writing. The results of the assessment on each cycle showed an increase in student learning outcomes in the form of exposition writing skills. The improvement can be seen from the results of the first learning assessment, cycle I, and cycle II. The percentage of class completeness in early learning was $61.76 \%$, in the first cycle was $73.53 \%$, and in the second
\end{abstract}


Edutainment : Jurnal Ilmu Pendidikan dan Kependidikan

Volume 8 Nomor 1 Edisi Januari - Juni 2020

cycle, it reached $94.12 \%$.Thus, it can be concluded, that learning with the City Forest of Sungailiat media is effective to improve the exposition text writing skills of students in Class VIII D at SMPN 2 Sungailiat.

Keywords: The City Forest Of Sungailiat; Media; Writing Skills; Exposition Text.

\section{PENDAHULUAN}

Keterampilan berbahasa meliputi empat aspek, yakni mendengar, berbicara, membaca, dan menulis. Keempat aspek tersebut harus dikuasai oleh siswa secara seimbang melalui pembelajaran. Namun, faktanya siswa merasa kesulitan pada penguasaan keterampilan tertentu. Umumnya, siswa merasa kesulitan pada keterampilan yang bersifat produktif, yaitu berbicara dan menulis.

Kesulitan tersebut berhubungan dengan kompleksnya materi dalam dua keterampilan tersebut. Misalnya keterampilan menulis dianggap sulit karena didalamnya melibatkan kemampuan berbahasa dan wawasan tentang materi yang ditulis. Pemilihan kata dan struktur kalimat harus berpadu dengan kemampuan menyusun materi secara terstruktur.

Kompleksnya proses menulis dikemukakan Yunus, dkk. (2014) bahwa menulis melibatkan sembilan proses berpikir. Proses tersebut yaitu mengingat pengetahuan yang telah diperoleh, menghubungkan pengetahuan yang sudah dimiliki dengan masalah yang ditulis, mengorganisasikan pengetahuan yang telah dimiliki, proses mengingat pengalaman yang dimiliki, memprediksi bagian tulisan selanjutnya, menjaga konsistensi tulisan, menggeneralisasikan informasi yang didapatkan, menerapkan informasi pada teks yang ditulis, dan mengevaluasi seluruh unsur tulisan, sehingga menjadi satu kesatuan yang utuh.

Kesulitan dalam menulis dialami oleh siswa kelas VIII di SMPN 2 Sungailiat, terutama kelas VIII D. Siswa kelas ini mengalami kesulitan dalam menulis teks eksposisi. Adapun pembelajaran dilakukan di ruang kelas dan halaman sekolah. Metode yang digunakan pada pembelajaran ini yaitu penugasan terbimbing.

Berdasarkan analisis hasil penilaian pada materi ini, siswa yang mampu mencapai nilai Ketuntasan Belajar Minimal (KBM) baru 21 dari 34 orang. Jadi, ketuntasannya baru $61,76 \%$. Nilai tertinggi pada penilaian yaitu 82 dan terendah 73 .

Siswa mengalami banyak kesulitan pada menentukan objek yang spesifik, menemukan dan menyusun informasi yang sesuai dengan tema. Di samping itu kesulitan-kesulitan kecil pada kebahasaan, misalnya ejaan dan penyusunan kalimat. Kadang-kadang kalimat yang digunakan, struktur dan maknanya belum logis. Sedangkan secara psikologis, siswa merasa 
Edutainment : Jurnal Ilmu Pendidikan dan Kependidikan

Volume 8 Nomor 1 Edisi Januari - Juni 2020

jenuh karena sudah terlalu sering pembelajaran menulis dilakukan di ruang kelas dan di lingkungan sekolah.

Siswa memerlukan sesuatu yang baru sekaligus memudahkan dan membuat mereka lebih senang dalam berproses. Untuk itu, maka dilakukan Penelitian Tindakan Kelas (PTK). PTK ini memanfaatkan Hutan Kota Sungailiat sebagai media. Dalam pelaksanaan perbaikan pembelajaran digunakan model Problem Based Learning (PBL).

Hutan Kota Sungailiat dipilih sebagai media langsung, karena memiliki keunikan dan lokasinya sangat dekat dengan sekolah, jaraknya sekitar 300 meter. Hutan ini luasnya hanya sekitar satu hektar tapi letaknya di tengah kota. Hutan tersebut menjadi pusat kegiatan masyarakat untuk berolahraga sekaligus rekreasi, menikmati keindahan dan kesejukannya. Hutan telah ditata sedemikian rupa, dilengkapi oleh jalur jogging, sarana bermain anak-anak, taman bacaan, toilet yang sangat bersih, bahkan kafe. Letaknya berhadapan dengan Masjid Agung Sungailiat yang akan menambah daya tarik tersendiri. Oleh karena itu, siswa dapat memilih objek tulisan sekaligus menjelaskan dan berargumen untuk menarik pembaca.

Dengan demikian, fokus PTK ini yaitu pemanfaatan Hutan Kota Sungailiat dalam meningkatkan keterampilan menulis eksposisi pada siswa kelas VIII D SMPN 2
Sungailiat. Maka, tujuan PTK ini yaitu untuk mengetahui efektivitas pembelajaran dengan media Hutan Kota Sungaliat dalam meningkatkan keterampilan menulis teks eksposisi pada siswa kelas VIII D di SMPN 2 Sungailiat. Efektivitas tersebut dapat dilihat melalui persentase ketuntasan kelas yang sekaligus mencerminkan peningkatan keterampilan siswa dalam menulis teks eksposisi.

Terdapat dua hasil penelitian sebelumnya yang identik dengan PTK ini. Penelitian tersebut dilakukan Anlisa, dkk. (2017) yang berjudul Peningkatan Pembelajaran Menulis Teks Hasil Observasi dengan Model Problem Based Learning Menurut simpulan hasil PTK tersebut, dengan Model PBL, keterampilan siswa kelas VII di SMPN 13 Bandar lampung dapat meningkat hingga tuntas $100 \%$.

Selain itu, terdapat hasil penelitian yang dilakukan oleh Yulia (2017) dengan judul Peningkatan Keterampilan Menulis Teks Laporan Hasil Observasi dengan Menggunakan Metode Field Trip. PTK ini dilakukan di SMKN 1 Rancah dengan simpulan bahwa pembelajaran dengan metode Field Trip dapat meningkatkan keterampilan siswa dalam menulis.

Tindakan ini untuk meningkatkan keterampilan siswa dalam menulis. Menulis, menurut Tarigan (2013) adalah menggunakan lambang-lambang suatu bahasa yang dipahami orang lain yang 
Edutainment : Jurnal Ilmu Pendidikan dan Kependidikan

Volume 8 Nomor 1 Edisi Januari - Juni 2020

merupakan representasi bagian dari kesatuan-kesatuan ekspresi bahasa, sehingga berbeda dengan melukis. Maka, jika seseorang hanya menggambar huruf-huruf sebagai lambang bunyi tidak dapat diketegorikan pada menulis.

Selanjutnya, Tarigan

menjelaskan fungsi menulis. Menulis dapat berfungsi untuk melatih para pelajar dalam berpikir, melatih berpikir kritis, mempermudah komunikasi, memperdalam persepsi, serta menyelesaikan masalah.

Selain itu, Yunus, dkk. (2014) mengemukakan enam fungsi menulis yaitu personal, untuk mencurahkan hal-hal yang bersifat pribadi. Contohnya pada buku harian dan surat. Instrumental (direktif), untuk meyakinkan, mempengaruhi sikap dan pikiran orang lain. Interaksional, untuk melakukan komunikasi sosial. Informatif, menjadi media informasi dan pengetahuan. Heuristik, sebagai sarana belajar atau mendapatkan informasi, dan yang terakhir estetis untuk mengekspresikan ide estetik.

Tindakan ini dilakukan pada materi menulis teks eksposisi. Tentang teks eksposisi dijelaskan Kosasih (2017) adalah teks yang berisi sejumlah argumentasi atau opini yang bertujuan untuk meyakinkan pembaca dan dapat disertai bujukan. Mengenai struktur teks eksposisi, menurut Kosasih (2017) memiliki tiga bagian, yakni tesis (isu, permasalahan, pandangan umum penulis), rangkaian argumen (pendapat- pendapat, fakta), dan penegasan ulang (simpulan/ rangkuman).

Tindakan ini dilakukan dalam pembelajaran, siswa melakukan serangkaian kegiatan pembelajaran untuk mendapatkan keterampilan menulis. Menurut Rusman (2014) pembelajaran adalah rangkaian kegiatan yang melibatkan berbagai komponen yang memiliki keterkaitan satu sama lain. Rusman berfokus pada interaksi antara siswa dengan unsur-unsur pendukung. Jika terjadi interaksi yang benar dan maksimal, maka akan menghasilkan pengetahuan baru yang bermakna.

$$
\text { Selanjunya Pranowo }
$$

menjelaskan dua komponen pembelajaran, yakni komponen utama dan pendukung. Komponen utama yaitu pengajar, materi, dan pembelajar. Komponen pendukung terdiri dari teknik, strategi, dan media pembelajaran.

Faktor pendukung yang sangat penting dalam tindakan ini yaitu media. Nuha (2016) menjelaskan, media pembelajaran adalah sesuatu yang bisa dimanfaatkan untuk mentransfer pesan dari guru kepada siswa. Media digunakan untuk menstimulasi pikiran, perasaan, perhatian, minat, dan perhatian pembelajar agar terjadi proses pembelajaran.

Berdasarkan pendapat Criticos melalui Daryanto (2016), media merupakan perangkat komunikasi sebagai perantara antara komunikator dan komunikan. 
Pendapat yang sejalan yaitu dari Heinich (Arsyad, 2015) bahwa media sebagai penghubung antara sumber dan penerima dalam berkomunikasi.

Pentingnya media diperjelas melalui pendapat Daryanto (2016). Fungsi media ialah menghindarkan dominasi unsur verbal; membantu siswa dari terbatasnya ruang, waktu, tenaga, dan kemampuan indera; lebih mendekatkan siswa pada sumber belajar; memberi kesempatan siswa lebih mandiri dalam belajar sesuai dengan tipe belajarnya; menyamakan rangsangan, pengalaman, dan persepsi dalam proses pembelajaran; dan menyalurkan pesan untuk merangsang perhatian.

Berdasarkan enam fungsi media pembelajaran tersebut dapat disimpulkan bahwa media berfungsi sebagai sarana untuk mengkonkretkan pesan dalam terbatasnya ruang waktu, tenaga, dan indera. Media pun berfungsi memberikan kesempatan siswa belajar mandiri dengan cara mendekatkannya dengan sumber belajar sesuai dengan tipe belajarnya.

Selanjutnya pentingnya lingkungan dalam pembelajaran dikemukakan Baharudin dan Esa (2015). Dijelaskan, bahwa faktor eksternal nonsosial yang mempengaruhi siswa dalam belajar, yakni lingkungan. Menurut Baharudin dan Esa, lingkungan alamiah, misalnya udara segar, sinar yang tidak terlalu redup dan tidak menyilaukan, suasana yang sejuk dan tenang memengaruhi proses belajar.

Dengan demikian, lingkungan merupakan faktor yang sangat berperan dalam kegiatan pembelajaran, karena lingkungan alamiah akan sangat membantu aktivitas pembelajaran.

Pemanfaatan media lingkungan dalam tindakan ini menggunakan model pembelajaran Problem Based Learning $(P B L)$. Pemilihan model ini didasari pendapat Finoza (2013) yang menjelaskan bahwa Problem Based Learning merupakan pembelajaran yang didasari masalah faktual dan kontekstual dalam kehidupan nyata atau disimulasikan. Maka sering dikaitkan dengan pembelajaran kontekstual.

Problem Based Learning didefinisikan oleh Tan (Rusman, 2014). Pembelajaran Berbasis Masalah ialah penggunaan berbagai macam kecerdasan yang diperlukan untuk melakukan konfirmasi terhadap tantangan dunia nyata, kemampuan untuk menghadapi segala sesuatu yang baru dan kompleksitas yang ada.

Langkah-langkah dalam PBL sangat cocok dengan pemanfaatan Hutan Kota sebagai media. Menurut Ismail (Rusman, 2014) langkah-langkahnya sebagai berikut: pertama, orientasi siswa pada masalah, menjelaskan tujuan pembelajaran, alat yang digunakan, dan memotivasi agar siswa aktif dalam kegiatan pembelajaran. Lalu yang 
Edutainment : Jurnal Ilmu Pendidikan dan Kependidikan

Volume 8 Nomor 1 Edisi Januari - Juni 2020

kedua, mengorganisasi siswa untuk belajar, membantu siswa mendefinisikan dan mengorganisasikan tugas yang berhubungan dengan masalah. Selanjutnya yang ketiga membimbing dalam pembentukan pengalaman individu/ kelompok, mendorong siswa untuk mengumpulkan informasi yang sesuai, melakukan eksperimen untuk mendapatkan penjelasan dan pemecahan masalah. Keempat, mengembangkan dan menyajikan karya, membantu siswa dalam merencanakan dan menyiapkan karya yang sesuai, seperti laporan dan membantu dalam berbagai tugas dengan temannya. Langkah terakhir, menganalisis dan mengevaluasi proses pemecahan masalah, membantu siswa dalam melakukan refleksi/ evaluasi terhadap penyelidikan dan proses yang telah dilakukan siswa.

Kegiatan pembelajaran harus dikelola sesuai dengan karakteristik siswa. Siswa SMP berada dalam fase remaja. Mappiare dalam Ali dan Mohammad memberikan batasan usia remaja, yakni antara 12-21 tahun untuk perempuan dan 1322 untuk laki-laki. Siswa SMP dari usianya termasuk pada rentang usia remaja. Maka, untuk mengetahui karakteristik siswa SMP dapat mempelajari karaktristik remaja.

Menurut Hurlock (Ali dan Mohammad, 2005) usia remaja (adolesence) bermakna luas, yakni meliputi kematangan mental, emosional, sosial, dam fisik. Maka, siswa SMP sudah memilki sikap tanggung jawab, sehingga sudah dapat belajar di ruang terbuka yang luas.

\section{METODE PENELITIAN}

\section{Tempat dan Waktu}

Penelitian Tindakan Kelas ini dilakukan di Hutan Kota Sungailiat yang berjarak kurang lebih $300 \mathrm{~m}$ dari SMPN 2 Sungailiat. Selain Hutan Kota Sungailiat, pembelajaran dilaksanakan juga di ruang kelas, yakni pada pertemuan kedua dalam setiap siklus.

Kegiatan perbaikan pembelajaran dilaksanakan dalam dua siklus. Sklus I dilaksanakan 18 September 2019 dan Siklus II 25 September 2019. Kegiatan ini menyusul pembelajaran awal tanggal 11 September 2019. Setiap kegiatan dilakukan pada dua jam pelajaran terakhir (7-8) selama 80 menit.

\section{Rancangan Pelaksanaan}

PTK dilaksanakan dengan model Hopkins. Dalam model ini PTK dilakukan setiap siklusnya terdiri dari empat langkah, yakni Perencanaan, pelaksanaan, pengamatan, dan refleksi (Arifah, 2017). Tahapan dalam PTK ini dirancang sesuai dengan model dan media yang digunakan. Tahap satu ialah perencanaan merupakan kegiatan persiapan sebelum pelaksanaan tindakan. Sebelum tindakan disusun Rencana Perbaikan Pembelajaran (RPP) yang sesuai dengan temuan pada tahap refleksi, model, dan media yang digunakan, 
Edutainment : Jurnal Ilmu Pendidikan dan Kependidikan

Volume 8 Nomor 1 Edisi Januari - Juni 2020

penilaian, hingga format pengamatan. Selain itu disusun skenario kegiatan secara detail mulai keluar kelas hingga mengakhiri kegiatan pembelajaran untuk setiap pertemuan.

Tahap kedua yaitu pelaksanaan yang dilakukan sesuai dengan tahapan-tahapan model PBL. Setiap siklus dilaksanakan dua pertemuan, pertemuan pertama untuk pembelajaran di Hutan Kota dan pertemuan kedua untuk proses penyempurnaan tulisan termasuk kebahasaan di kelas dan evaluasi. Tindakan dalam pembelajaran menulis dengan media Hutan Kota Sungailiat mengacu pada lima langkah model $P B L$. Langkah 1-3 untuk pertemuan pertama dan langkah 4-5 untuk pertemuan kedua.

Pertama, orientasi siswa terhadap masalah. Siswa menyimak penjelasan tentang tujuan pembelajaran dan aktivitas yang akan dilakukan, permasalahan yang akan dibahas, serta teknik evaluasi. Kegiatan awal ini berfungsi untuk memberikan gambaran tentang kegiatan pembelajaran yang akan dilakukannya secara detil hingga siswa paham apa yang harus dilakukannya. Kedua, siswa mengorganisasi materi dan tugas. Pada tahap ini siswa mengorganisasikan tugas yang berhubungan dengan pembelajaran menulis teks. Dalam tindakan, pada tahap ini siswa dibantu membentuk kelompok dan diingatkan tentang struktur dan cara memanfaatkan lingkungan Hutan Kota Sungailiat sebagai objek dalam menulis.

Ketiga, siswa mendapat bimbingan dalam pengamatan, baik secara individu maupun kelompok. Siswa dibimbing dalam menemukan dan mengamati bagian-bagian hutan sebagai bahan menulis. Setiap siswa dibebaskan mengamati dan mencatat hal-hal yang ditemukan dan dapat dijadikan bahan tulisan yang akan dipadukan dengan hasil siswa lain dalam kelompoknya. Keempat, mengembangkan dan menyajikan hasil karya. Pada tahap ini siswa mendiskusikan cara memadukan hasil pengamatannya ke dalam tulisan. Selanjutnya siswa menuangkan hasil diskusinya ke dalam tulisan sesuai dengan struktur teks eksposisi. Pada tahap ini pun siswa melakukan penyuntingan. Tahapan ini dilakukan di kelas pada pertemuan berikutnya. Pada kegiatan menyunting ini siswa memperbaiki ejaan, tata kalimat, pilihan kata, isi, dan merapikan tulisan. Karya siswa dalam pembelajaran yaitu teks yang sesuai dengan pembelajaran yang dilakukan.

Kelima, menganalisis dan mengevaluasi proses pemecahan masalah. Masing-masing kelompok mengumpulkan teks yang ditulisnya. Dilanjutkan dengan merekonstruksi pemikiran dan kegiatan pembelajaran yang baru dilakukan para siswa. Guru membaca secara cepat teks-teks hasil pembelajaran siswa untuk menemukan kekurangan-kekurangannya. Menemukan 
kekurangan ini sebagai bahan evaluasi dan untuk diketahui siswa sebagai bahan dalam kegiatan mengedit tulisan tersebut pada pertemuan berikutnya.

Tahap ketiga yaitu tahap pengamatan. Pengamatan dilakukan ketika proses pembelajaran berlangsung yang dilakukan oleh peneliti dan dibantu oleh seorang guru mata pelajaran Bahasa Indonesia lain. Adapun yang diamati yaitu kolaborasi siswa dalam kelompok, keaktifan termasuk gairah siswa, interaksi siswa dengan guru. Aktivitas guru pun diamati oleh teman sejawat yang akan dituangkan dalam catatan khusus. Tahap keempat merupakan kegiatan refleksi sebagai tahap penentu kelanjutan siklus dan perencanaan. Jika diperlukan untuk siklus selanjutnya, maka disusun perencanaannya. Selain itu, kelemahan dan kelebihan, serta keunikan yang ditemukan dibahas dalam tahap ini.

\section{Penilaian dan Patokan Ketuntasan Kelas}

Penilaian pada tindakan ini menggunakan metode tes unjuk kerja, yakni menulis teks eksposisi. Penentuan nilai keterampian menulis menggunakan pedoman yang meliputi ketepatan struktur, ketepatan isi, penggunaan bahasa, dan teknik penulisan teks. Patokan ketuntasan adalah KBM pada materi menulis teks eksposisi yaitu 79. Maka, dalam pengolahan data, nilai yang diperoeh siswa dibandingkan dengan KBM, sehingga para siswa dapat diketahui tuntas atau belum tuntas. Sedangkan patokan untuk mengakhiri siklus perbaikan yaitu ketuntasan kelas. Jika minimal 92\% siswa di kelas VIII D telah mencapai ketuntasan, perbaikan pembelajaran diakhiri.

\section{HASIL DAN PEMBAHASAN}

\section{Deskripsi Hasil Tindakan}

Pelaksanaan perbaikan pembelajaran pada PTK ini dilakukan sesuai rancangan, yakni empat tahap setiap siklusnya. Pada kedua siklus perbaikan, mulai perencanaan hingga refeksi tidak ada perbedaan yang prinsip. Tahapan PTK dan langkah-langkah perbaikan pembelajaran telah diuraikan secara rinci pada bagian metode penelitian. Pada bagian ini dideskripsikan hasil tindakan pada kedua siklus. Berdasarkan hasil pengamatan secara umum pada perbaikan siklus I, siswa tampak lebih bergairah belajar di Hutan Kota Sungailiat, sehingga nilai yang diperolehnya mengalami peningkatan. Siswa yang tuntas pembelajarannya sebanyak 25 orang. Dengan demikian, ketuntasan pada siklus I sebesar 73,53\%. Nilai tertinggi yang diperoleh siswa ialah 90 dan terendah 75 . Selanjutnya dilaksanakan perbaikan pembelajaran pada siklus II. Berdasarkan hasil diskusi dengan guru pengamat dalam refleksi pada siklus I siswa masih terpengaruh suasana hingga kurang fokus, baik dalam mengumpulkan data maupun dalam kolaborasi menyatukan data untuk 
Edutainment : Jurnal Ilmu Pendidikan dan Kependidikan

Volume 8 Nomor 1 Edisi Januari - Juni 2020

menjadi tulisan. Maka pada siklus II $\begin{array}{llll}\text { Siklus I } & 25 & 9 & 73,53\end{array}$ dilakukan dengan membatasi ruang gerak siswa dan memberi batas waktu penyelesaian konsep tulisan. Selain itu, aktivitas siswa lebih diawasi. Siswa yang tidak melakukan pembelajaran sesuai arahan guru diminta membersihkan daun-daun di jalur joging.

Setelah dilakukan penilaian, hasil pembelajaran siklus II pun menunjukkan peningkatan yang lebih tinggi. Siswa yang mencapai ketuntasan hasil belajar sejumlah 32 orang. Maka persentasi ketuntasan kelas sudah mencapai 94,12\%. Adapun nilai tertinggi pada siklus ini mencapai 92 dan terendah 78. Berdasarkan hasil penilaian pada siklus II, tingkat ketuntasan kelas telah mencapai persentase patokan yang telah ditentukan sebesar 92\%. Oleh karena itu, tindakan perbaikan pembelajaran diakhiri pada siklus II.

Berikut rangkuman hasil pembelajaran siswa kelas VIII D di SMPN 2 Sungailiat pada keterampilan menulis eksposisi dalam bentuk tabel.

Tabel 1. Ketuntasan Persiklus

\begin{tabular}{cccc}
\hline Kegiatan & Jumlah & Jumlah & Ketuntasan \\
& Tuntas & Tidak & Kelas \\
& & Tuntas & $(\%)$
\end{tabular}

\begin{tabular}{llll}
\hline Prasiklus & 21 & 13 & 61,76
\end{tabular}


Edutainment : Jurnal Ilmu Pendidikan dan Kependidikan

Volume 8 Nomor 1 Edisi Januari - Juni 2020

hingga mengandung persuasi (Kosasih, 2017).

Perbaikan pembelajaran diawali dari siklus I yang hasil penilaiannya menunjukkan adanya peningkatan keterampilan siswa jika dibandingkan dengan pembelajaran prasiklus. Peningkatan pada siklus I sebesar $11,77 \%$ yang artinya siswa yang mencapai KBM sebanyak 25 orang, hanya bertambah empat orang. Peningkatan nilai terendah dan tertinggi pun relatif rendah, yakni 75 dan 90. Maka, peningkatan pada siklus I masih jauh dari patokan ketuntasan kelas. Memang siswa SMP yang dikategorikan pada usia remaja oleh Hurlock (Ali dan Mohammad, 2005) sudah memiliki kamatangan untuk melakukan banyak hal dengan bertanggung jawab. Namun, siswa kelas VIII D SMPN 2 Sungailiat belum terbiasa melakukan pembelajaran di ruang publik. Para siswa masih melihat hutan kota secara global, belum mampu memfokuskan pada salah satu objek di sana. Perhatian siswa terkadang masih terbagi dengan keinginan untuk bermain, sehingga kolaborasi dalam menyusun data yang diperoleh kurang maksimal. Berdasarkan pengamatan, siswa masih banyak yang tidak memanfaatkan waktu diskusi.

Dengan demikian, apa yang disimpulkan dalam sebuah teori masih sangat tergantung pada situasi dan kondisi. Siswa SMPN 2 Sungailiat dalam 
Edutainment : Jurnal Ilmu Pendidikan dan Kependidikan

Volume 8 Nomor 1 Edisi Januari - Juni 2020

pembelajaran berfungsi untuk meminimalisir verbal. Terlalu banyak guru menjelaskan materi dengan lisan akan membuat siswa merasa jenuh dan sulit mengingat dan memahaminya, sehingga guru perlu membatasi verbal. Selanjutnya, media membantu siswa dari terbatasnya ruang, waktu, tenaga, dan kemampuan indera. Pemanfaatan Hutan Kota Sungailiat membantu siswa untuk mendapatkan ruang belajar yang lebih rekreatif dan luas serta waktu pembelajaran lebih lama. Waktu yang digunakan dalam pembelajaran di hutan kota dua jam pelajaran terakhir hingga para siswa masih bisa berlama-lama di sana untuk melanjutkan kegiatan dengan tetap mendapat pengawasan guru ditambah orang tua. Siswa pun bisa belajar di bagian-bagian hutan yang disukainya hingga ada kelompok yang memilih di bawah pohon besar, ada yang memilih di atas batu besar.

Selain itu, mendekatkan siswa pada sumber belajar, karena setiap bagian di hutan kota dapat dijadikan bahan tulisan. Misalnya ada siswa yang menulis tentang "Hutan Kota Sungailiat sebagai Pendukung Kesehatan". Siswa yang lain menulis tentang "Hutan Kota Sungailiat sebagai Alternatif Rekreasi Anak-anak", ada juga yang menulis tentang "Hutan Kota Sungailiat sebagai Paru-paru Kota”. Masih banyak ide-ide siswa dalam menulis teks eksposisi. Fungsi lain menurut Daryanto ialah memberi kesempatan siswa lebih 
Edutainment : Jurnal Ilmu Pendidikan dan Kependidikan

Volume 8 Nomor 1 Edisi Januari - Juni 2020

Rusman (2014) interaksi antara siswa dengan unsur-unsur pendukung menentukan keberhasilan pembelajaran. Hasil penelitian ini pun sejalan dengan hasil penelitian sebelumnya yang dilakukan oleh Yulia (2017) yang menggunakan metode Field Trip dan Anlisa, dkk. (2017) yang menggunakan model PBL. Hasil kedua penelitian tersebut menunjukkan bahwa media alam dan model PBL dapat meningkatkan keterampilan menulis teks hasil observasi siswa. Dengan demikian, dapat disimpulkan bahwa pembelajaran dengan media Hutan Kota Sungailiat dapat meningkatkan keterampilan siswa dalam menulis teks eksposisi.

\section{SIMPULAN DAN SARAN}

Berdasarkan hasil penelitian dapat disimpulkan bahwa Hutan Kota efektif untuk meningkatkan keterampilan menulis teks eksposisi pada siswa keas VIII D di SMP Negeri 2 Sungailiat. Efektivitasnya dapat dilihat melalui peningkatan persentase ketuntasan kelas. Pada pembelajaran prasiklus ketuntasan kelas 61,76\%, meningkat setelah dilakukan perbaikan pembelajaran siklus I menjadi 73,53\%. Kemudian meningkatkan besar terjadi setelah perbaikan pembelajaran siklus II mencapai 94,12.

\section{DAFTAR PUSTAKA}

Ali, Mohammad dan Mohammad Asrori. (2005). Psikologi Remaja, Perkembangan Peserta Didik. Jakarta: Bumi Aksara.

Anlisa, Y., Widodo, M., \& Rusminto, N. E. (2017). Peningkatan pembelajaran menulis teks hasil observasi melalui model problem based learning. $J$ SIMBOL (Bahasa, Sastra, Dan Pembelajarannya), 5(2).

Arifah, Fita Nur. 2017. Panduan Penelitian Tindakan Kelas \& Karya Tulis Ilmiah untuk Guru. Yogyakarta: Araska.

Arsyad, Azhar. (2015). Media Pembelajaran. Depok: PT Rajagrafindo Persada.

Baharudin, H. dan Esa Nur Wahyuni. (2015). Teori Belajar \& Pembelajaran. Yogyakarta: Ar-Ruzz Media.

Daryanto. (2016). Media Pembelajaran, Peranannya Sangat Penting dalam Mencapai Tujuan Pembelajaran. Yogyakarta: Gava Media.

Finoza, Lamuddin. (2013). Komposisi Bahasa Indonesia. Jakarta: Diksi Insan Mulia.

Kosasih, E. (2017) Bahasa Indonesia SMP/MTs Kelas VIII Edisi Revisi. Jakarta: Kementerian Pendidikan dan Kebidayaan.

Nuha, Ulin. (2016). Ragam Metodologi \& Media Pembelajaran Bahasa Arab. Yogyakarta: DIVA Press.

Pranowo. (2014). Teori Belajar Bahasa.Yogyakarta: Puataka Pelajar.

Rusman. (2014). Model-model Pembelajaran Mengembangkan Profesionalisme Guru. Depok: PT Rajagrafindo.

Yulia, W. (2017). Peningkatan Keterampilan Menulis Teks Laporan Hasil Observasi Dengan Menggunakan Metode Field Trip. DIKSATRASIA, 1(2), 349-357.

Yunus, M., dkk. (2014) Keterampilan Menulis. Tangerang Selatan: Unversitas Terbuka. 